\title{
A combination of metformin and insulin is an effective treatment that benefits the cardiovascular and cerebrovascular system in individuals with type 1 diabetes mellitus
}

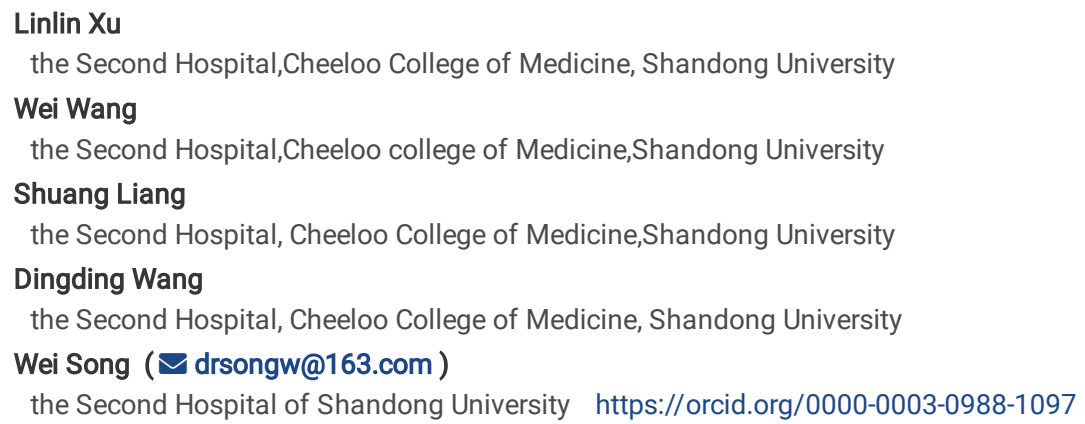




\section{Abstract}

Background

This study aims to further clarify whether there are cardiovascular and cerebrovascular benefits associated with insulin treatment combined with metformin in individuals with type 1 diabetes.

Methods

Electronic databases were searched for randomized controlled trials in which the efficacy and safety of metformin were compared with those of a placebo for the treatment of cardiovascular and cerebrovascular disease among type 1 diabetes patients, and a meta-analysis was conducted.

Results

Thirteen cardiovascular studies were identified. In the metformin group, mean carotid intimal media thickness was significantly reduced by 0.03 mm, ascending aortic pulse wave velocity by $6.3 \mathrm{~m} / \mathrm{s}$, descending aortic wall shear stress by $1.77 \mathrm{dyn} / \mathrm{cm}^{2}$, insulin daily dose by $0.05 \mathrm{U} / \mathrm{kg} / \mathrm{d}$, body weight by 2.27 $\mathrm{kg}$, fat-free mass by $1.32 \mathrm{~kg}$, body mass index by $0.58 \mathrm{~kg} / \mathrm{m}^{2}$, hip circumference by $0.29 \mathrm{~m}$, and low-density lipoprotein by $0.16 \mathrm{mmol} / \mathrm{L}$. In the metformin group, flow-mediated dilation was increased by $1.29 \%$, glucose infusion rate/insulin by $18.22 \mu \mathrm{lU} / \mu \mathrm{L}$, and waist-to-hip ratio by 0.02 . The metformin group showed no differences in blood pressure, reactive hyperemia index, waist circumference, triglyceride, total cholesterol, high-density lipoprotein cholesterol, or body mass index $Z$ score. For cerebrovascular studies were identified. But none of them had a risk factor assessment.

Conclusions

There is strong evidence supporting wider use of metformin to improve cardiovascular and cerebrovascular disease risk among individuals with type 1 diabetes, not just obese or adults.

\section{Background}

The incidence of type 1 diabetes mellitus (T1DM) is increasing annually. Notably, a study of 19 countries showed that only $30 \%$ of T1DM patients had HbA1c $<7.5 \%$ and that at least $30 \%$ of T1DM patients had poor HbA1c $(>9.0 \%)^{1}$. The complications of diabetes can be reduced by intensive insulin treatment to achieve normal $\mathrm{HbA} 1 \mathrm{c}$. However, the excessive use of insulin is another problem and often reaches 1.5-2 $\mathrm{U} / \mathrm{kg} / \mathrm{d}$, resulting in weight gain, which may be caused by the increase in low-density lipoprotein cholesterol (LDL) or blood pressure (BP) ${ }^{2}$. In adolescents with T1DM, the adolescent surge of hormones and changes in body composition make HbA1c more difficult to control and can lead to insulin resistance (IR) and excessive weight gain; the body mass index (BMI) of T1DM adolescents has been shown to increase faster than that of nondiabetic adolescents ${ }^{3}$. IR also accelerates the progression of atherosclerosis ${ }^{4}$.

Atherosclerosis is the basis of cardiovascular disease (CVD), the main cause of death in individuals with T1DM ${ }^{5}$. Even if T1DM patients can maintain a good $\mathrm{HbA1c}$, their risk of cardiovascular morbidity is still three-fold higher than that of the general population ${ }^{6}$. Recent research has found that metformin may improve vascular endothelial dysfunction, which is the first step in the development of atherosclerosis in patients with T1DM ${ }^{7}$. Metformin may reduce carotid intimal media thickness (CIMT) in patients with T1DM ${ }^{8}$. Even if statins are used for 2 to 4 years, they cannot change cIMT in individuals with T1DM ${ }^{9}$. Studies have shown that atherosclerosis exists in children with T1DM ${ }^{10}$, but vascular functional and structural disorders can be reversed. The effects of adding metformin to the treatment for T1DM on reducing $\mathrm{HbA} 1 \mathrm{c}$ have been inconsistent.

Diabetes raises the risk of ischaemic stroke through increased atherosclerosis and endothelial dysfunction while also leading to a slower and less complete recovery following stroke ${ }^{11}$. Brain blood vessel dysfunction in diabetic subjects can result in a high level of bleeding following stroke, which worsens prognosis and hinders functional recovery after stroke ${ }^{12}$. Metformin has recently been shown to ameliorate many of the negative effects of stroke by acting through AMPK-mediated pathways ${ }^{13}$. Cerebrovascular diseases that already were classified as neurological diseases and no longer belong to CVD after 2018 were separated the statistics and the discussion in this article.

This study aims to further clarify whether the cardiovascular and cerebrovascular system benefits from the addition of metformin to insulin treatment in individuals with T1DM.

\section{Methods}

\section{Search strategy and study selection}

In this meta-analysis, two of the study authors searched the MEDLINE, EMBASE, and Cochrane Library databases for articles published through 15 July 2020 , using the Mesh and text terms "metformin," "diabetes mellitus, type 1" and "carotid intima thickness, atherosclerosis, lipid profile, vascular function, cardiovascular disease" or "Stroke, transient ischemic attack, cerebral hemorrhage, subarachnoid hemorrhage" to identify randomized clinical trials (RCTs) that compared the efficacy and safety of metformin with those of a placebo for the treatment of atherosclerosis among T1DM patients. We also manually scanned reference lists from trials and review articles to identify other relevant publications ${ }^{14}$.

\section{Data extraction}


All potentially eligible scientific reports assessing the effects of metformin compared to those of a placebo were identified by two authors. Each full-text article was reviewed by these two authors ${ }^{14}$. The data were then extracted, and both authors independently assessed the study quality using a standardized approach. Any disagreement in extracted data was settled by other investigators to reach a final decision. The data extracted included the first author, year of publication, country where the study was conducted, number of participants, number of patients lost to follow-up, mean age of participants, diabetes duration, intervention duration, clinical outcomes, and safety outcomes. Studies were excluded if they were case reports, letters, comments, or editorials or if no quantitative outcomes were reported ${ }^{15}$. The primary clinical outcomes of interest were $\mathrm{CIMT}^{9}$, reactive hyperemia index $(\mathrm{RHI})^{16}$, flow-mediated dilation $(\mathrm{FMD})^{17}$, pulse wave velocity $(\mathrm{PWV})^{18}$, wall shear stress $(\mathrm{WSS})^{19}$, and glucose infusion rate/insulin $(\mathrm{M} / \mathrm{I})^{20}$. The secondary outcomes included lipid profiles, which consisted of total cholesterol (TC), triglycerides (TG), high-density lipoprotein (HDL), and LDL; BP; waist and hip circumferences; HbA1c; BMl; homocysteine(HCY) and total insulin daily dose (TIDD). Safety outcomes included severe hypoglycemic events, diabetic ketoacidosis (DKA) events, and gastrointestinal adverse events.

\section{Data analysis}

Two authors independently assessed the risk of bias for each included trial using the Cochrane Risk of Bias Tool for Randomized Controlled Trials and the criteria outlined in the Cochrane Handbook for Systematic Reviews of Interventions ${ }^{18}$. Summary estimates were obtained using a fixed-effects model, and a random-effects model was used when $\mathrm{I}^{2}>50 \%$. We measured the treatment effect by calculating risk ratios (RRs) with $95 \%$ confidence intervals (Cls) for dichotomous data and mean differences (MDs) with $95 \%$ Cls for continuous data. All statistical analyses were performed using the Cochrane Review statistical software, Review Manager 5.2.

\section{Results}

\section{Description of studies}

The electronic searches resulted in the identification of 378 cardiovascular disease records: MEDLINE 185; EMBASE, 136; and Cochrane, 57. After removing duplicates, 103 records remained, and after examination of the titles and abstracts of these records, we eliminated any studies that clearly did not match our inclusion criteria. We obtained full-text copies of the 33 potentially eligible articles and subjected these to further evaluation. We excluded 9 articles because they were controlled clinical trials, not RCTs. Finally, 24 articles were found to be eligible and included in the meta-analysis (Ahmed $2016^{21}$, Anderson $2013^{22}$, Anderson $2016^{23}$, Anderson $2017^{7}$, Bjornstad $2018^{24}$, Burchardt $2013^{25}$, Burchardt $2016^{26}$, Jacobsen $2009^{27}$, Khan $2006^{28}$, Lund $2008^{29}$, Lund $2009^{30}$, Lunder

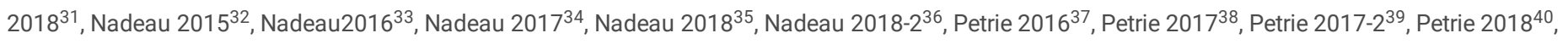
Pitocco2013 41 , Wiromrat 2018 42 , Xu 2018 ${ }^{43}$ ). Twenty-four articles were from 13 different studies published at different times: Nadeau 2015, 2016, 2017, 2018, and 2018-2 reported data from the same study, and thus, we used Nadeau 2018 as a representative publication. In addition, Lund 2008 and Lund 2009 presented a similar situation, and we used Lund 2009 as the representative article; Petrie 2016, 2017, 2017-2 and 2018 reported data from the same study, and Petrie 2017 was selected as the representative paper. Anderson 2016, 2017, and 2013 reported data from the same study, and we chose Anderson 2017 as the representative publication. Finally, Bjornstad 2018 and Wiromrat 2018 reported data from the same study, so we selected Bjornstad 2018 as the representative article. However, the main results of these articles were different, so they were all included (Figure 1). The thirteen different studies included data from 1030 T1DM patients: 555 patients with a combined insulin and metformin treatment and 475 patients with a combined insulin and placebo treatment. Details of the studies included are shown in Table 1.

The electronic searches resulted in the identification of 0 cerebrovascular disease record. We removed the "type 1 diabetes" Mesh and text word to search. The identification of cerebrovascular records was 20: MEDLINE 20; EMBASE, 3; and Cochrane, 1. After removing duplicates, 20 records remained, and after examination of the titles and abstracts of these records, we eliminated any studies that clearly did not match our inclusion criteria. We obtained full-text copies of the 10 potentially eligible articles and subjected these to further evaluation. We excluded 3 articles because they were protocol and 2 articles because metformin was basic drug and 1 article was comment. Finally, 4 articles were found to be eligible and included in the analysis. However, the patients of these 4 articles are not T1DM(Ghotbi2013 ${ }^{44}$, Charytan2019 ${ }^{45}$, Mellbin200746, Hertog2013 $\left.{ }^{47}\right)$. Details of the studies included are shown in Table 2.

\section{Primary clinical outcomes}

Four studies reported data regarding the mean cIMT (Anderson 2017, Bjornstad 2018, Nadeau 2018, Petrie 2018). There were 350 patients in the metformin group and 302 patients in the placebo group (Heterogeneity: $P=0.06 ; I^{2}=59 \%$ ); therefore, a random-effects model was used for the analysis. The overall analysis showed that metformin can significantly reduce the mean cIMT by $0.03 \mathrm{~mm}(\mathrm{P}<0.00001)$. Data describing the effects of metformin on maximum cIMT were consistent (Anderson 2017, Bjornstad 2018, Burchardt 2016, Petrie 2018). The pooled analysis showed a significant difference between the metformin and placebo groups (MD -0.04, 95\% $\mathrm{Cl}=-0.07-0.0, \mathrm{Z}=2.08, \mathrm{P}=0.04$ ) (Figure 2).

FMD data was provided by Anderson 2017, Lunder 2018, and Pitocco 2013 (heterogeneity: $P=0.004 ;\left.\right|^{2}=82 \%$ ). Compared with the placebo, metformin significantly increased FMD by $1.29 \%(P=0.02)$. The sensitivity analysis determined that the heterogeneity disappeared after the removal of Anderson 2017 $\left(\mathrm{P}=0.19 ; \mathrm{I}^{2}=42 \%\right)$. Metformin significantly increased $\mathrm{FMD}$ by $2.03 \%(95 \% \mathrm{Cl}=1.12-2.93, \mathrm{P}<0.0001)$. Three studies provided data on $\mathrm{RHI}$ with different treatment regimens (Nadeau 2018, Lunder 2018, Petrie 2018) (heterogeneity: $\left.P<0.00001 ; I^{2}=94 \%\right)$. Metformin slightly increased $R H I$ by $0.16 \%(P=0.45)($ Figure 3 ).

There were 2 studies that provided data on ascending aortic PWV (AA PWV) (Bjornstad 2018, Lunder 2018) (heterogeneity: $P=0.04, I^{2}=75 \%$ ). Compared with the placebo, metformin significantly reduced AA PWV by $6.3 \mathrm{~m} / \mathrm{s}(\mathrm{P}<0.00001)$. Descending aortic PWV (DA PWV) data was provided by Bjornstad 2018 and Nadeau 2018. These 2 studies presented significant heterogeneity $\left(P<0.0001 ; l^{2}=95 \%\right)$. Metformin slightly reduced DA PWV by $0.22 \mathrm{~m} / \mathrm{s}(\mathrm{P}=0.32)($ Figure 4$)$. 
The maximum descending aortic WSS (DA WSS) data were provided by Bjornstad 2018 and Nadeau 2018 (heterogeneity: $P<0.00001, I^{2}=99 \%$ ). The metformin group showed a significant reduction in the maximum DA WSS of $1.77 \mathrm{dyn} / \mathrm{cm}^{2}(P=0.02)$.

$\mathrm{M} / \mathrm{I}$ data was provided by Bjornstad 2018 and Nadeau 2018 (heterogeneity: $\mathrm{P}<0.00001 ; \mathrm{I}^{2}=95 \%$ ). The metformin group exhibited significantly increased $\mathrm{M} / \mathrm{I}$ by $18.22 \mu \mathrm{IU} / \mu \mathrm{L}(\mathrm{P}<0.00001)$.

\section{Secondary clinical outcomes}

Seven studies provided data on TIDD (Anderson 2017, Bjornstad 2018, Jacobsen 2009, Lund 2009, Nadeau 2018, Petrie 2018, Xu 2018), with 418 patients in the metformin group and 367 patients in the placebo group. Heterogeneity was observed among the included studies $\left(P=0.002 ; 1^{2}=71 \%\right)$. The metformin group exhibited significantly reduced TIDD by $0.05 \mathrm{U} / \mathrm{kg} / \mathrm{d}(P<0.00001)$. Metformin significantly reduced daily insulin dosage by $5.22 \mathrm{U} / \mathrm{d}(P<0.00001)($ Figure 5$)$.

Eight studies provided data on the body weight of patients (Pitocco 2013, Petrie 2018, Nadeau 2018, Lund 2009, Khan 2006, Jacobsen 2009, Burchardt 2013, Bjornstad 2018), presenting significant heterogeneity $\left(P=0.001 ;\left.\right|^{2}=70 \%\right)$; metformin significantly reduced body weight by $2.27 \mathrm{~kg}(P<0.00001)$. Sensitivity analysis was performed, and heterogeneity disappeared after the removal of Jacobsen $2009\left(P=0.61 ; l^{2}=0 \%\right)$. Metformin significantly reduced body weight by $1.90 \mathrm{~kg}$ (95\% Cl=-2.07-1.73, P<0.00001). Eight studies provided BMI data (Xu 2018, Pitocco 2013, Nadeau 2018, Lunder 2018, Lund 2009, Burchardt 2013, Bjornstad 2018, Ahmed 2016) (heterogeneity: $P=0.49 ; l^{2}=0 \%$ ). Metformin also significantly reduced BMI $0.58 \mathrm{~kg} / \mathrm{m}^{2}(\mathrm{P}<0.00001)$. Bjornstad 2018 and Nadeau 2018 provided data on BMI Z scores (heterogeneity: $\left.P<0.00001 ; l^{2}=99 \%\right)$. Compared with the placebo group, the metformin group showed no effect on the BMI $\mathrm{Z}$ score $(\mathrm{P}=0.33)$. Furthermore, Bjornstad 2018 and Anderson 2017 provided data on fat-free mass. Heterogeneity was not found ( $\mathrm{P}=0.31)$; metformin significantly reduced fat-free mass by $1.32 \mathrm{~kg}(\mathrm{P}<0.00001)$, as shown in Figure 6.

Eight studies provided TC data (Ahmed 2016, Anderson 2017, Bjornstad 2018, Burchardt 2013, Jacobsen 2009, Khan 2006, Lund 2009, Nadeau 2018). The included studies had significant heterogeneity $\left(P<0.00001 ; I^{2}=95 \%\right)$. The heterogeneity disappeared after the removal of Lund $2009\left(P=0.35 ; l^{2}=10 \%\right)$, but the findings were still not statistically significant (95\% $\mathrm{Cl}=-0.08-0.06, \mathrm{P}=0.79)$ (Figure 7). Data on HDL were provided in 8 studies (Ahmed 2016, Anderson 2017, Bjornstad 2018, Burchardt 2013, Jacobsen 2009, Khan 2006, Lund 2009, Nadeau 2018) (heterogeneity: $P<0.00001 ; I^{2}=81 \%$ ). Compared with the placebo, metformin had no effect on HDL (95\% Cl=-0.08-0.00, P=0.05) (Figure 8). Seven studies provided LDL data (Anderson 2017, Bjornstad 2018, Burchardt 2013, Jacobsen 2009, Khan 2006, Lund 2009, Petrie 2018) (heterogeneity: $P<0.00001 ; I^{2}=86 \%$ ). Compared with the placebo, metformin significantly reduced LDL by $0.16 \mathrm{mmol} / \mathrm{L}(P=0.01)$. Sensitivity analysis was performed to determine the heterogeneity after the removal of Lund $2009\left(P=1.00 ; I^{2}=0 \%\right)$. Metformin significantly reduced LDL by $0.11 \mathrm{mmol} / \mathrm{L}$ ( $95 \% \mathrm{Cl}=-0.16-0.06, \mathrm{Z}=4.11, \mathrm{P}<0.0001$ ) (Figure 9). Data on TG were provided in 7 studies (Ahmed 2016, Anderson 2017, Bjornstad 2018, Burchardt 2013, Jacobsen 2009, Khan 2006, Lund 2009) (heterogeneity: $P=0.003 ;\left.\right|^{2}=69 \%$ ). Metformin slightly increased TG by 0.05 $\mathrm{mmol} / \mathrm{L}(\mathrm{P}=0.33)$. The heterogeneity disappeared after the removal of Bjornstad $2018\left(P=0.15 ; \mathrm{I}^{2}=38 \%\right)$ and Jacobsen $2009\left(P=0.82 ; I^{2}=0 \%\right)$, but the results were still not statistically significant (Figure 10).

Anderson 2017 and Lund 2009 provided data on hip circumference (heterogeneity: $P=0.82 ; I^{2}=0 \%$ ). Metformin significantly reduced hip circumference by 0.29 m ( $P<0.00001)$. Five studies provided data on waist circumference (Anderson 2017, Lund 2009, Lunder 2018, Nadeau 2018, Xu 2018). Significant heterogeneity existed among the 5 studies $\left(P<0.0001 ; I^{2}=86 \%\right)$. Metformin had no effect on waist circumference $(P=0.67)$. The heterogeneity disappeared after the removal of Lunder 2018 and $\mathrm{Xu} 2018\left(\mathrm{P}=0.38 ; \mathrm{I}^{2}=0 \%\right)$. Metformin significantly reduced waist circumference by $0.36 \mathrm{~m}(95 \% \mathrm{Cl}=-0.53-0.18, \mathrm{Z}=4.02$, $\mathrm{P}<0.0001$ ). Anderson 2017 and Lund 2009 provided data on the waist-to-hip ratio (heterogeneity: $\left.P=0.29 ; I^{2}=9 \%\right)$. Metformin significantly reduced the waist-tohip ratio by $0.02(\mathrm{P}<0.0001)$ (Figure 11).

Six studies provided data on BP (heterogeneity: $\left.\mathrm{P}=0.002 ; \mathrm{I}^{2}=73 \%\right)$. Metformin had no effect on $\mathrm{BP}(\mathrm{P}=0.34)$. The heterogeneity among the studies disappeared after the removal of Bjornstad $2018\left(P=0.12 ; I^{2}=46 \%\right)$. The metformin group showed a tendency toward reduced systolic BP ( $\left.P=0.12\right)$. The heterogeneity among the studies disappeared after removing Jacobsen $2009\left(P=0.45 ; I^{2}=0 \%\right)$. Interestingly, the pooled analysis showed that metformin significantly reduced the diastolic $\mathrm{BP}$ by $2.01 \mathrm{mmHg}(95 \% \mathrm{Cl}=-2.69-1.34, \mathrm{Z}=5.83, \mathrm{P}<0.00001)$ (Figure 12$)$.

Homocysteine, as a risk factor for stroke, was not mentioned in the 4 articles. These four articles are not systematically analyzed just reviewed. Ghotbi 2013 showed that metformin treatment reduced the rate of nonfatal stroke compared to insulin treatment. Charytan 2019 showed that metformin treatment at baseline was associated with reduced cardiovascular and cerebrovascular complications in patients with diabetes and CKD. Mellbin 2007 showed that the risk for non-fatal myocardial infarction and stroke increased significantly in patients on insulin ( $\mathrm{HR} 1.73,95 \% \mathrm{Cl} 1.26-2.37$; $\mathrm{P}=0.0007)$, whereas this risk was lower among those on metformin (HR 0.63, 95\% Cl 0.42-0.95; P= 0.03). Hertog 2013 showed that metformin treatment improved glucose tolerance following cerebral ischaemia in non-diabetic patients, which is a cause of post-stroke damage.

Regarding the incidence of adverse events among patients with T1DM treated with insulin combined with metformin, 6 studies provided data on hypoglycemic events, 5 studies provided data on ketoacidosis, and 6 studies provided data on gastrointestinal adverse reactions, including adverse events experienced by those treated with insulin alone. None of the patients dropped out of treatment due to side effects or the study procedures.

\section{Discussion}

The incidence of T1DM complications is as high as $96.5 \%^{48}$. The main cause of death among patients with T1DM is cardiovascular complications, and patients urgently need a program to reduce cardiovascular disease risk. Therefore, we conducted a meta-analysis to further confirm the cardiovascular benefits of adding metformin to the treatment plan among patients with T1DM. We analyzed 13 high-quality RCT studies on the effects of cardiovascular risk factors in T1DM patients and found that insulin combined with metformin significantly reduced the mean and maximum cIMT compared with the effects of insulin alone among T1DM patients. The use of cIMT as a primary outcome is highly consistent with cardiovascular outcomes, with a positive predictive value 
of $96 \%{ }^{49}$. This result showed that metformin had a direct effect on preventing the progression of atherosclerosis among T1DM patients, although not by reducing $\mathrm{HbA} 1 \mathrm{c}$ because there were no changes in $\mathrm{HbA} 1 \mathrm{c}$ in any of the studies.

Another important result was that metformin can significantly improve vascular endothelial function in patients with T1DM. Combined insulin and metformin treatment significantly increased FMD by $1.29 \%$. FMD is considered a very important standard for the noninvasive evaluation of the vascular endothelium and is widely used in the early detection and prognosis evaluation of a variety of cardiovascular diseases ${ }^{17}$. The treatment of T1DM with insulin combined with metformin significantly reduced AA PWV by $6.3 \mathrm{~m} / \mathrm{s}$. PWV is an indicator that can reflect the degree of vascular sclerosis, and an increase in PWV reflects endothelial dysfunction ${ }^{18}$. Endothelial dysfunction is the early manifestation of atherosclerotic plaques before angiography or ultrasound and is the initiating factor of atherosclerosis; moreover, the endothelium is the target organ of cardiovascular and cerebrovascular disease risk factors ${ }^{50}$.

The use of metformin can reduce not only LDL but also the use of statins ${ }^{51}$. Some scholars have proposed that in T1DM patients, the risk of CVD is reduced by approximately $20 \%$ for every $0.5 \mathrm{mmol} / \mathrm{L}$ reduction in $L D L{ }^{52}$. Our meta-analysis showed that metformin reduced LDL by $0.16 \mathrm{mmol} / \mathrm{L}$ and reduced the risk of CVD by $6.4 \%$. As seen above, metformin protects vascular endothelial function and reduces LDL level, thus reducing lipid deposition and ultimately reducing cIMT. As a possible mechanism, metformin, via 5'-adenosine monophosphate-activated protein kinase (AMPK) activation, has been thought to directly reduce atherosclerosis and support the molecular effects of statins on cholesterol metabolism ${ }^{53}$. In addition, metformin can inactivate methylglyoxal through the non-AMPK pathway, improve endothelial function, and inhibit the formation of glycosylation end products ${ }^{54}$.

Insulin combined with metformin treatment in patients with T1DM can significantly reduce weight by $2.27 \mathrm{~kg}, \mathrm{BMI}$ by $0.58 \mathrm{~kg} / \mathrm{m}^{2}, \mathrm{TIDD}$ by $0.05 \mathrm{U} / \mathrm{kg} / \mathrm{d}$, daily insulin by $5.22 \mathrm{U} / \mathrm{d}$, fat-free mass by $1.32 \mathrm{~kg}$, and hip circumference by $0.29 \mathrm{~m}$. In addition, metformin reduced the daily insulin requirement by approximately $16 \%$. These findings all shows a decrease in central fat. When the data were subanalyzed by sex, only the waist circumference and BMI Z score of women decreased significantly ${ }^{32}$. Perhaps appetite suppression may partly explain the significant weight loss ${ }^{27}$. Metformin can significantly increase the $\mathrm{M} / \mathrm{I}$ by $18.22 \mu \mathrm{IU} / \mu \mathrm{L}$. These results suggest that metformin continues to improve IR, which is an increasingly recognized factor that contributes to the progression of CVD in T1DM patients ${ }^{4}$. Therefore, treatments targeting IR in T1DM patients have become an effective method for the prevention of cardiovascular diseases.

In the past 10 years, there have been 5 meta-analyses on the efficacy of insulin combined with metformin for treating patients with T1DM. The meta-analysis by Al-Khalifa showed that there is no evidence of improving HbA1c but strong evidence of reducing TIDD and BMI. The combination therapy was deemed as safe $^{55}$. The meta-analysis by Liu (2016) showed that the effect may be different between overweight/obese adolescents and nonobese adolescents and can increase the risk of adverse events ${ }^{56}$. Liu's (2015) meta-analysis showed that metformin can reduce TIDD, weight, and lipid levels. Metformin does not increase the incidence of hypoglycemia or ketoacidosis ${ }^{57}$. Vella (2010) concluded that metformin can reduce TIDD ${ }^{58}$. The meta-analysis conducted by Meng showed that insulin combined with metformin could significantly reduce TC and LDL in T1DM patients ${ }^{14}$. Those meta-analyses did not include a marker of poor cardiovascular prognosis. The combination of insulin and metformin was associated with a slight increase in gastrointestinal reactions leading to hypoglycemic events in T1DM patients. Therefore, when adding metformin to the T1DM treatment regimen, it is necessary to closely monitor blood glucose and adjust TIDD in a timely manner to reduce the occurrence of hypoglycemia.

Metformin can improve cardiovascular disease risk factors, which are also risk factors for cerebrovascular disease. However, another risk factor for cerebrovascular disease is hyperhomocysteinemia. Zhang 2016 Meta-analysis suggested that metformin could decrease the concentration of Hcy when exogenous B-group vitamins or folic acid supplementation was given ${ }^{59}$. Therefore, metformin can decrease the risk of stroke and has recently been shown to be capable of improving recovery following stroke ${ }^{60}$. Metformin can improve the neurological function and oxidative stress status of acute stroke patients with type 2 diabetes, and its mechanism may be related to the AMPK/mTOR signaling pathway and oxidative stress ${ }^{61}$. The underlying metformin mechanisms include decreasing mitochondrial dysregulation, oxidative stress/reactive oxygen species, blood-brain-barrier breakdown, inflammation of the brain, and neuronal apoptosis ${ }^{60}$. Therefore, there should be more clinical trials to determine whether metformin can be added to improve stroke in T1DM, type 2 diabetes, and Non-diabetic patients, basing on metformin decreasing risk factors of cerebrovascular disease and underlying mechanisms.

Pharmacogenomics must also be considered when patients with T1DM are treated with metformin. The maximum dose of metformin is $2500 \mathrm{mg} / \mathrm{d}$, and a box of metformin (Glucophage) is $\$ 4.30$, and the annual cost is $\$ 315.40$. The average duration of the included studies was 8.5 months. Metformin is a costeffective therapy.

\section{Conclusion}

Multiple factors proved that metformin can prevent the progression of atherosclerosis among T1DM patients, significantly improve endothelial function, reduce lipid deposition, reduce IR, and ultimately reduce cIMT among T1DM patients. There is strong evidence supporting wider use of metformin to improve CVD and cerebrovascular disease risk among T1DM patients, not just among obese or adults.

\section{Abbreviations}

type 1 diabetes mellitus (T1DM), blood pressure (BP), lipoprotein cholesterol (LDL), insulin resistance (IR), body mass index (BMI), cardiovascular disease (CVD), carotid intimal media thickness (cIMT), randomized clinical trials (RCTs), reactive hyperemia index (RHI), flow-mediated dilation (FMD), pulse wave velocity (PWV), wall shear stress (WSS), glucose infusion rate/insulin (M/I), total cholesterol (TC), triglycerides (TG), high-density lipoprotein (HDL), homocysteine $(\mathrm{HCY})$, and total insulin daily dose (TIDD), diabetic ketoacidosis (DKA), confidence intervals (Cls), risk ratios (RRs), mean differences (MDs), Descending aortic PWV (DA PWV), ascending aortic PWV (AA PWV), descending aortic WSS (DA WSS). 


\section{Declarations}

\section{Acknowledgements}

Not applicable.

\section{Ethics approval and consent to participate}

This study was approved by the Second Hospital, Cheeloo College of Medicine, Shandong University(KYLL-2017(KJ)P-0016).

\section{Consent for publication}

The consent to publish was obtained from all participants in this study.

\section{Availability of data and materials}

Data sharing not applicable to this article as no datasets were generated or analyzed during the current study.

\section{Competing interests}

The authors declare that they have no competing interests.

\section{Funding}

This work was supported by the National Natural Science Foundation of China (81901106), the Youth Talent Found of the 2nd Hospital of Shandong University (2018YT09), Jinan clinical medical science and technology innovation plan (201907002).

\section{Authors' contributions}

W.S. designed the article. W.S. and L.X. have made contributions to the acquisition of data. W. W. and S. L. contributed to analysis and interpretation of data. W.S. drafted the work. D. W. reviewed the manuscript. All authors reviewed and approved the final manuscript.

\section{References}

1. McKnight JA, Wild SH, Lamb MJ, Cooper MN, Jones TW, Davis EA, et al. Glycaemic control of Type 1 diabetes in clinical practice early in the 21 st century: an international comparison. Diabet Med. 2015;32:1036-50,

2. Cleland SJ, Fisher BM, Colhoun HM, Sattar N, Petrie JR. Insulin resistance in type 1 diabetes: what is 'double diabetes' and what are the risks? Diabetologia. 2013;56:1462-70,.

3. Szadkowska A, Pietrzak I, Mianowska B, Bodalska-Lipinska J, Keenan HA, Toporowska-Kowalska E, et al. Insulin sensitivity in Type 1 diabetic children and adolescents. Diabet Med. 2008;25:282-8,

4. Schauer IE, Snell-Bergeon JK, Bergman BC, Maahs DM, Kretowski A, Eckel RH, et al. Insulin resistance, defective insulin-mediated fatty acid suppression, and coronary artery calcification in subjects with and without type 1 diabetes: The CACTI study. Diabetes. 2011;60:306-14,.

5. Livingstone SJ, Levin D, Looker HC, Lindsay RS, Wild SH, Joss N, et al. Estimated life expectancy in a Scottish cohort with type 1 diabetes, $2008-2010$. Jama. 2015;313:37-44.

6. Lind M, Svensson AM, Rosengren A. Glycemic control and excess mortality in type 1 diabetes. N Engl J Med. 2015;372:880-1,

7. Anderson JJA, Couper JJ, Giles LC, Leggett CE, Gent R, Coppin B, et al. Effect of Metformin on Vascular Function in Children With Type 1 Diabetes: A 12Month Randomized Controlled Trial. J Clin Endocrinol Metab. 2017;102:4448-56.

8. Petrie JR, Chaturvedi N, Ford I, Brouwers M, Greenlaw N, Tillin T, et al. Cardiovascular and metabolic effects of metformin in patients with type 1 diabetes (REMOVAL): a double-blind, randomised, placebo-controlled trial. Lancet Diabetes Endocrinol. 2017;5:597-609,.

9. Harrington J, Pena AS, Gent R, Hirte C, Couper J. Aortic intima media thickness is an early marker of atherosclerosis in children with type 1 diabetes mellitus. J Pediatr. 2010;156:237-41.

10. Marcovecchio ML, Woodside J, Jones T, Daneman D, Neil A, Prevost T, et al. Adolescent Type 1 Diabetes Cardio-Renal Intervention Trial (AdDIT): urinary screening and baseline biochemical and cardiovascular assessments. Diabetes Care. 2014;37:805-13.

11. Huynh W, Kwai N, Arnold R, Krishnan AV, Lin CS, Vucic S, et al. The Effect of Diabetes on Cortical Function in Stroke: Implications for Poststroke Plasticity. Diabetes. 2017;66:1661-70.

12. Ergul A, Elgebaly MM, Middlemore ML, Li W, Elewa H, Switzer JA, et al. Increased hemorrhagic transformation and altered infarct size and localization after experimental stroke in a rat model type 2 diabetes. BMC Neurol. 2007;7:33,

13. Ashabi G, Khalaj L, Khodagholi F, Goudarzvand M, Sarkaki A. Pre-treatment with metformin activates Nrf2 antioxidant pathways and inhibits inflammatory responses through induction of AMPK after transient global cerebral ischemia. Metab Brain Dis. 2015;30:747-54,

14. Meng H, Zhang A, Liang Y, Hao J, Zhang X, Lu J. Effect of metformin on glycaemic control in patients with type 1 diabetes: A meta-analysis of randomized controlled trials. Diabetes Metab Res Rev 34, e2983,(2018).

15. Song W, Zhao F, Liang S, Li G, Xue J. Is a Combination of a GnRH Agonist and Recombinant Growth Hormone an Effective Treatment to Increase the Final Adult Height of Girls with Precocious or Early Puberty? International journal of endocrinology 2018, 1708650,(2018).

Page 6/15 
16. Liu W, Meng M, Chen J, Wang L, Sun Z, Li X, et al. Reactive Hyperemia Index in Patients on Maintenance Hemodialysis: Cross-sectional Data from a Cohort Study. Scientific reports. 2017;7:45757.

17. Rodriguez-Miguelez P, Seigler N, Harris RA. Ultrasound Assessment of Endothelial Function: A Technical Guideline of the Flow-mediated Dilation Test. Journal of visualized experiments: JoVE,(2016).

18. Ogawa O, Onuma T, Kubo S, Mitsuhashi N, Muramatsu C, Kawamori R. Brachial-ankle pulse wave velocity and symptomatic cerebral infarction in patients with type 2 diabetes: a cross-sectional study. Cardiovasc Diabetol. 2003;2:10,.

19. Valencia A, Morales H, Rivera R, Bravo E, Galvez M. Blood flow dynamics in patient-specific cerebral aneurysm models: the relationship between wall shear stress and aneurysm area index. Medical engineering physics. 2008;30:329-40.

20. Chan CL, Pyle L, Morehead R, Baumgartner A, Cree-Green M, Nadeau KJ. The role of glycemia in insulin resistance in youth with type 1 and type 2 diabetes. Pediatr Diabetes. 2017;18:470-7.

21. Ahmed FW, Rider R, Glanville M, Narayanan K, Razvi S, Weaver JU. Metformin improves circulating endothelial cells and endothelial progenitor cells in type 1 diabetes: MERIT study. Cardiovascular diabetology. 2016;15:116,.

22. Anderson J, Peña AS, Sullivan T, Gent R, D'Arcy B, Olds T, et al. Does metformin improve vascular heath in children with type 1 diabetes? Protocol for a one year, double blind, randomised, placebo controlled trial. BMC pediatrics 13,(2013).

23. Anderson J, Leggett C, Gent R, Giles L, Couper J, Pena AS. Metformin improves vascular function in children and adolescents with type 1 diabetes: The adelaide metformin RCT trial. Endocrine Reviews 37,(2016).

24. Bjornstad P, Schafer M, Truong U, Cree-Green M, Pyle L, Baumgartner A, et al. Metformin Improves Insulin Sensitivity and Vascular Health in Youth With Type 1 Diabetes Mellitus. Circulation. 2018;138:2895-907.

25. Burchardt P, Zawada A, Tabaczewski P, Naskręt D, Kaczmarek J, Marcinkaniec J, et al. Metformin added to intensive insulin therapy reduces plasma levels of glycated but not oxidized low-density lipoprotein in young patients with type 1 diabetes and obesity in comparison with insulin alone: a pilot study. Pol Arch Med Wewn. 2013;123:526-32.

26. Burchardt P, Zawada A, Kaczmarek J, Marcinkaniec J, Wysocki H, Wierusz-Wysocka B, et al. Association between adjunctive metformin therapy in young type 1 diabetes patients with excess body fat and reduction of carotid intima-media thickness. Pol Arch Med Wewn. 2016;126:514-20,

27. Jacobsen IB, Henriksen JE, Beck-Nielsen H. The effect of metformin in overweight patients with type 1 diabetes and poor metabolic control. Basic Clin Pharmacol Toxicol. 2009;105:145-9.

28. Khan ASA, McLoughney CR, Ahmed AB. The effect of metformin on blood glucose control in overweight patients with Type 1 diabetes. Diabet Med. 2006;23:1079-84.

29. Lund SS, Tarnow L, Astrup AS, Hovind P, Jacobsen PK, Alibegovic AC, et al. Effect of adjunct metformin treatment in patients with type-1 diabetes and persistent inadequate glycaemic control. A randomized study. PLOSONE 3,(2008).

30. Lund SS, Tarnow L, Astrup AS, Hovind P, Jacobsen PK, Alibegovic AC, et al. Effect of adjunct metformin treatment on levels of plasma lipids in patients with type 1 diabetes. Diabetes Obes Metab. 2009;11:966-77,.

31. Lunder M, Janic M, Japelj M, Juretic A, Janez A, Sabovic M. Empagliflozin on top of metformin treatment improves arterial function in patients with type 1 diabetes mellitus. Cardiovasc Diabetol. 2018;17:153,

32. Nadeau KJ, Chow K, Alam S, Lindquist K, Campbell S, McFann K, et al. Effects of low dose metformin in adolescents with type I diabetes mellitus: a randomized, double-blinded placebo-controlled study. Pediatr Diabetes. 2015;16:196-203,.

33. Nadeau K, Miller K, Nathan B, Bacha F, Katz M, Simmons J, et al. Effect of metformin on endothelial function in overweight adolescents with type 1 diabetes (T1D). Pediatric Diabetes. 2016;17:152-3.

34. Nadeau KJ, Cree-Green M, Baumgartner A, Williams J, Garcia-Reyes Y, Wadwa P, et al. Metformin's impact on insulin resistance (IR) and fitness in youth with type 1 diabetes (T1D). Diabetes. 2017;66:A76,

35. Nadeau KJ, Schafer M, Bjornstad P, Browne L, Truong U, Green M, et al. Metformin improves vascular haemodynamic function in youth with type 1 diabetes. J Investig Med. 2018;66:69-70.

36. Nadeau KJ, Bjornstad P, Schfer M, Browne L, Baumgartner A, Reyes YG, et al. Metformin improves insulin resistance (IR) and vascular health in youth with type 1 diabetes (T1D). Diabetes. 2018;67:A63,

37. Petrie JR, Chaturvedi N, Ford I, Hramiak I, Hughes AD, Jenkins A, et al. Metformin in type 1 diabetes: Methods and baseline characteristics of the REMOVAL trial. Diabetologia. 2016;59:354,

38. Petrie JR, Chaturvedi N, Ford I, Hramiak I, Hughes AD, Jenkins AJ, et al. Metformin in adults with type 1 diabetes: Design and methods of REducing with MetfOrmin Vascular Adverse Lesions (REMOVAL): An international multicentre trial. Diabetes Obesity Metabolism. 2017;19:509-16,.

39. Petrie JR, Chaturvedi N, Ford I, Brouwers MCGJ, Greenlaw N, Tillin T, et al. Cardiovascular and metabolic effects of metformin in patients with type 1 diabetes (REMOVAL): a double-blind, randomised, placebo-controlled trial. The Lancet Diabetes Endocrinology. 2017;5:597-609,

40. Petrie JR, Chaturvedi N, Ford I, Brouwers MCG, Greenlaw N, Hramiak I, et al. The removal trial: Metformin reduces progression of mean carotid intimamedia thickness (cIMT) in never smokers with type 1 diabetes. Diabetologia. 2018;61:555,

41. Pitocco D, Zaccardi F, Tarzia P, Milo M, Scavone G, Rizzo P, et al. Metformin improves endothelial function in type 1 diabetic subjects: A pilot, placebocontrolled randomized study. Diabetes Obesity Metabolism. 2013;15:427-31.

42. Wiromrat P, Bjornstad P, Roncaljimenez CA, Schäfer M, Baumgartner A, Pyle L, et al. Serum uromodulin (SUMOD) inversely correlates with aortic stiffness in type 1 diabetes (T1D) youth. Diabetes. 2018;67:A115, 
43. Xu W, Luo S, Liang W, Deng H, Wu Z, Zheng X, et al. Effect of metformin added to insulin on glycemic control and insulin sensitivity in adolescents with type 1 diabetes: A 24-week, prospective, randomized clinical trial. Journal of Diabetes Investigation. 2018;9:108,

44. Ghotbi AA, Køber L, Finer N, James WP, Sharma AM, Caterson I, et al. Association of hypoglycemic treatment regimens with cardiovascular outcomes in overweight and obese subjects with type 2 diabetes: a substudy of the SCOUT trial. Diabetes Care. 2013;36:3746-53,

45. Charytan DM, Solomon SD, Ivanovich P, Remuzzi G, Cooper ME, McGill JB, et al. Metformin use and cardiovascular events in patients with type 2 diabetes and chronic kidney disease. Diabetes Obes Metab. 2019;21:1199-208,.

46. Mellbin LG, Malmberg K, Norhammar A, Wedel H, Rydén L. The impact of glucose lowering treatment on long-term prognosis in patients with type 2 diabetes and myocardial infarction: a report from the DIGAMI 2 trial. Eur Heart J. 2008;29:166-76,.

47. den Hertog HM, Vermeer SE, Zandbergen AA, Achterberg S, Dippel DW, Algra A, et al. Safety and feasibiLIty of Metformin in patients with Impaired glucose Tolerance and a recent TIA or minor ischemic stroke (LIMIT) trial - a multicenter, randomized, open-label phase II trial. Int J Stroke. 2015;10:105-9,.

48. Rawshani A, Rawshani A, Franzen S, Eliasson B, Svensson AM, Miftaraj M, et al. Mortality and Cardiovascular Disease in Type 1 and Type 2 Diabetes. N Engl J Med. 2017;376:1407-18.

49. Peters SA, den Ruijter HM, Grobbee DE, Bots ML. Results from a carotid intima-media thickness trial as a decision tool for launching a large-scale morbidity and mortality trial. Circ Cardiovasc Imaging. 2013;6:20-5.

50. Leone A. Markers of Atherosclerotic Disease: What do they Mean? Current Opinion and Future Trends. Curr Pharm Des. 2016;22:7-17.

51. Ratner R, Goldberg R, Haffner S, Marcovina S, Orchard T, Fowler S, et al. Impact of intensive lifestyle and metformin therapy on cardiovascular disease risk factors in the diabetes prevention program. Diabetes Care. 2005;28:888-94.

52. Kearney PM, Blackwell L, Collins R, Keech A, Simes J, Peto R, et al. Efficacy of cholesterol-lowering therapy in 18,686 people with diabetes in 14 randomised trials of statins: a meta-analysis. Lancet. 2008;371:117-25,

53. Misra P. AMP activated protein kinase: a next generation target for total metabolic control. Expert Opin Ther Targets. 2008;12:91-100.

54. Almabrouk TA, Ewart MA, Salt IP, Kennedy S. Perivascular fat, AMP-activated protein kinase and vascular diseases. Br J Pharmacol. 2014;171:595-617.

55. Al Khalifah RA, Alnhdi A, Alghar H, Alanazi M, Florez ID. The effect of adding metformin to insulin therapy for type 1 diabetes mellitus children: A systematic review and meta-analysis. Pediatr Diabetes. 2017;18:664-73.

56. Liu W, Yang XJ. The Effect of Metformin on Adolescents with Type 1 Diabetes: A Systematic Review and Meta-Analysis of Randomized Controlled Trials. International journal of endocrinology 2016, 3854071,(2016).

57. Liu C, Wu D, Zheng X, Li P, Li L. Efficacy and safety of metformin for patients with type 1 diabetes mellitus: a meta-analysis. Diabetes technology therapeutics. 2015;17:142-8.

58. Vella S, Buetow L, Royle P, Livingstone S, Colhoun HM, Petrie JR. The use of metformin in type 1 diabetes: a systematic review of efficacy. Diabetologia. 2010;53:809-20.

59. Zhang Q, Li S, Li L, Li Q, Ren K, Sun X, et al. Metformin Treatment and Homocysteine: A Systematic Review and Meta-Analysis of Randomized Controlled Trials. Nutrients 8,(2016).

60. Leech T, Chattipakorn N, Chattipakorn SC. The beneficial roles of metformin on the brain with cerebral ischaemia/reperfusion injury. Pharmacol Res. 2019;146:104261,.

61. Zhao M, Li XW, Chen Z, Hao F, Tao SX, Yu HY, et al. Neuro-Protective Role of Metformin in Patients with Acute Stroke and Type 2 Diabetes Mellitus via AMPK/Mammalian Target of Rapamycin (mTOR) Signaling Pathway and Oxidative Stress. Med Sci Monit. 2019;25:2186-94,.

\section{Tables}

Table 1 Details of the cardiovascular disease studies 


\begin{tabular}{|c|c|c|c|c|c|c|c|c|c|c|c|}
\hline Study & Country & $\begin{array}{l}\text { Metformin } \\
\text { dose }\end{array}$ & $\begin{array}{l}\text { Patients } \\
\text { (n) }\end{array}$ & Lost & $\begin{array}{l}\text { Follow- } \\
\text { up, } \\
\text { Months }\end{array}$ & $\begin{array}{l}\text { Age, } \\
\text { years }\end{array}$ & $\mathrm{HbA} 1 \mathrm{c}, \%$ & $\begin{array}{l}\text { Diabetes } \\
\text { duration, } \\
\text { years }\end{array}$ & $\mathrm{BMI}, \mathrm{kg} / \mathrm{m}^{2}$ & Insulin dose & Outcome \\
\hline $\begin{array}{l}\text { Ahmed } \\
2016\end{array}$ & UK & $\begin{array}{l}1000 \mathrm{mg} \\
\text { bid }\end{array}$ & 32 & 0 & 2 & $46 \pm 13$ & $7.3 \pm 0.9$ & $23 \pm 13.6$ & 28.7 & $44 u / d$ & $\mathrm{TC}, \mathrm{LDL}$, \\
\hline $\begin{array}{l}\text { Anderson } \\
2017, \\
2013, \\
2016\end{array}$ & Australia & $\begin{array}{l}1000 \mathrm{mg} \\
\text { bid }\end{array}$ & 90 & 11 & 12 & $13.6 \pm 3.5$ & 8.4 & $5.2 \pm 3.6$ & I & $0.82 \pm 0.22 \mathrm{u} / \mathrm{kg} / \mathrm{d}$ & $\begin{array}{l}\text { insulin dc } \\
\text { BMl, cIM- } \\
\text { GTN }\end{array}$ \\
\hline $\begin{array}{l}\text { Bjornstad } \\
2018, \\
\text { Wiromrat } \\
2018\end{array}$ & UA & $\begin{array}{l}1000 \mathrm{mg} \\
\text { bid }\end{array}$ & 48 & 4 & 3 & $16.8 \pm 2.6$ & $8.0 \pm 3.7$ & $7.8 \pm 4.2$ & $25.4 \pm 4.4$ & $0.83 \pm 0.25 \mathrm{u} / \mathrm{kg} / \mathrm{d}$ & $\begin{array}{l}\text { insulin dc } \\
\mathrm{BMI}^{-\mathrm{ClM}^{-}}\end{array}$ \\
\hline $\begin{array}{l}\text { Burchardt } \\
2013\end{array}$ & Poland & $\begin{array}{l}1000- \\
2550 \mathrm{mg} \\
\mathrm{qd}\end{array}$ & 68 & 16 & 6 & $33.6 \pm 11.1$ & $9.0 \pm 1.9$ & $15.9 \pm 7.8$ & $29.5 \pm 3.2$ & I & $\mathrm{TC}, \mathrm{LDL}$ \\
\hline $\begin{array}{l}\text { Burchardt } \\
2016\end{array}$ & Poland & $\begin{array}{l}1000 \\
\pm 500 \mathrm{mg} \\
\mathrm{qd}\end{array}$ & 84 & 0 & 6 & $33.2 \pm 11.5$ & $8.5 \pm 1.7$ & $\begin{array}{l}\text { at least } 5 \\
\text { year }\end{array}$ & / & $0.6 \pm 0.16 \mathrm{U} / \mathrm{kg} / \mathrm{d}$ & cIMT \\
\hline $\begin{array}{l}\text { Jacobsen } \\
2009\end{array}$ & Denmark & $\begin{array}{l}1000 \mathrm{mg} \\
\text { bid }\end{array}$ & 24 & 1 & 12 & $40.4 \pm 11.7$ & $8.37 \pm 0.20$ & $19.1 \pm 10.1$ & $29.2 \pm 3.0$ & $56.8 \pm 2.9 \mathrm{U} / \mathrm{d}$ & TC, LDL, E \\
\hline $\begin{array}{l}\text { Khan } \\
2006\end{array}$ & UK & $\begin{array}{l}850 \mathrm{mg} \\
\text { tid }\end{array}$ & 18 & 3 & 4 & $48 \pm 12$ & $8.6 \pm 1.4$ & $19 \pm 10$ & $31.3 \pm 2.6$ & $60 \pm 14 \mathrm{U} / \mathrm{d}$ & TG, TC \\
\hline $\begin{array}{l}\text { Lund } \\
\text { 2008, } \\
\text { Lund2009 }\end{array}$ & Denmark & $\begin{array}{l}1000 \mathrm{mg} \\
\text { bid }\end{array}$ & 100 & 8 & 12 & $46.1 \pm 11.6$ & $9.48 \pm 0.99$ & 30 & $26.11 \pm 3.55$ & $0.74 \pm 0.26 \mathrm{U} / \mathrm{kg} / \mathrm{d}$ & $\mathrm{TC}, \mathrm{LDL}$ \\
\hline $\begin{array}{l}\text { Lunder } \\
2018\end{array}$ & Slovenia & $\begin{array}{l}2000 \mathrm{mg} \\
\mathrm{qd}\end{array}$ & 20 & 0 & 3 & $46.4 \pm 3.9$ & $7.9 \pm 0.2$ & $23.2 \pm 4.8$ & $28.0 \pm 0.3$ & I & FMD \\
\hline $\begin{array}{l}\text { Nadeau } \\
2015, \\
2016, \\
2017, \\
2018, \\
2018-2\end{array}$ & UK & $\begin{array}{l}2000 \mathrm{mg} \\
\mathrm{qd}\end{array}$ & 80 & 7 & 3.2 & $15.9 \pm 1.7$ & $9.5 \pm 1.3$ & $6.7 \pm 3.6$ & $23.5 \pm 3.0$ & $1.21 \pm 0.24 \mathrm{U} / \mathrm{kg} / \mathrm{d}$ & $\begin{array}{l}\text { RHI, insul } \\
\text { dose, wai } \\
\text { circumfel } \\
\text { BMI, BP }\end{array}$ \\
\hline $\begin{array}{l}\text { Petrie } \\
2016, \\
2017 \\
2017-2, \\
2018\end{array}$ & $\begin{array}{l}\text { Five } \\
\text { countries }\end{array}$ & $\begin{array}{l}1000 \mathrm{mg} \\
\text { bid }\end{array}$ & 428 & 101 & 36 & $55 \pm 8.5$ & $8.0 \pm 0.82$ & $34 \pm 10.8$ & $28.4 \pm 4.3$ & $0.63 \pm 0.26 \mathrm{U} / \mathrm{kg} / \mathrm{d}$ & cIMT \\
\hline $\begin{array}{l}\text { Pitocco } \\
2013\end{array}$ & Italy & $\begin{array}{l}850 \mathrm{mg} \\
\text { tid }\end{array}$ & 42 & 0 & 6 & $46 \pm 8$ & $7.24 \pm 0.90$ & $9.2 \pm 0.7$ & $28.7 \pm 2.1$ & $0.61 \pm 0.22 \mathrm{U} / \mathrm{kg} / \mathrm{d}$ & FMD, NM \\
\hline Xu 2018 & China & $\begin{array}{l}\leq 1500 \\
\mathrm{mg} \mathrm{qd}\end{array}$ & 17 & 0 & 6 & $12-18$ & $9.22 \pm 1.69$ & / & $18.33 \pm 1.71$ & $1.03 \pm 0.23 \mathrm{u} / \mathrm{kg} / \mathrm{d}$ & $\begin{array}{l}\text { HbA1c, B } \\
\text { waist } \\
\text { circumfel } \\
\text { insulin dc }\end{array}$ \\
\hline
\end{tabular}

Table 2 Details of the cerebrovascular disease studies

\begin{tabular}{|llll|}
\hline Study & Model & $\mathrm{n}$ & Major findings \\
\hline Chotbi2013 & $\begin{array}{l}\text { Overweight } \\
\text { patients with }\end{array}$ & 8192 & decreased rate of nonfatal stroke compared to insulin treatment. \\
\hline T2DM & $\begin{array}{l}\text { Patients with } \\
\text { diabetes mellitus } \\
\text { and CKD }\end{array}$ & 4038 & Metformin treatment at baseline was associated with reduced cardiovascular complications. \\
\hline Mellbin2007 & $\begin{array}{l}\text { type 2 diabetic } \\
\text { patients }\end{array}$ & 1181 & $\begin{array}{l}\text { the risk for non-fatal myocardial infarction and stroke increased significantly in patients on insulin (HR } \\
1.73,95 \% \text { Cl 1.26-2.37; P= 0.0007), whereas this risk was lower among those on metformin (HR 0.63, 95\% } \\
\text { Cl 0.42-0.95; P= 0.03). }\end{array}$ \\
\hline Hertog2013 & $\begin{array}{l}\text { Non-diabetic } \\
\text { patients }\end{array}$ & 40 & $\begin{array}{l}\text { Metformin improved glucose tolerance following stroke in non-diabetic patients, which is a cause of post- } \\
\text { stroke damage. }\end{array}$ \\
\hline
\end{tabular}

\section{Figures}




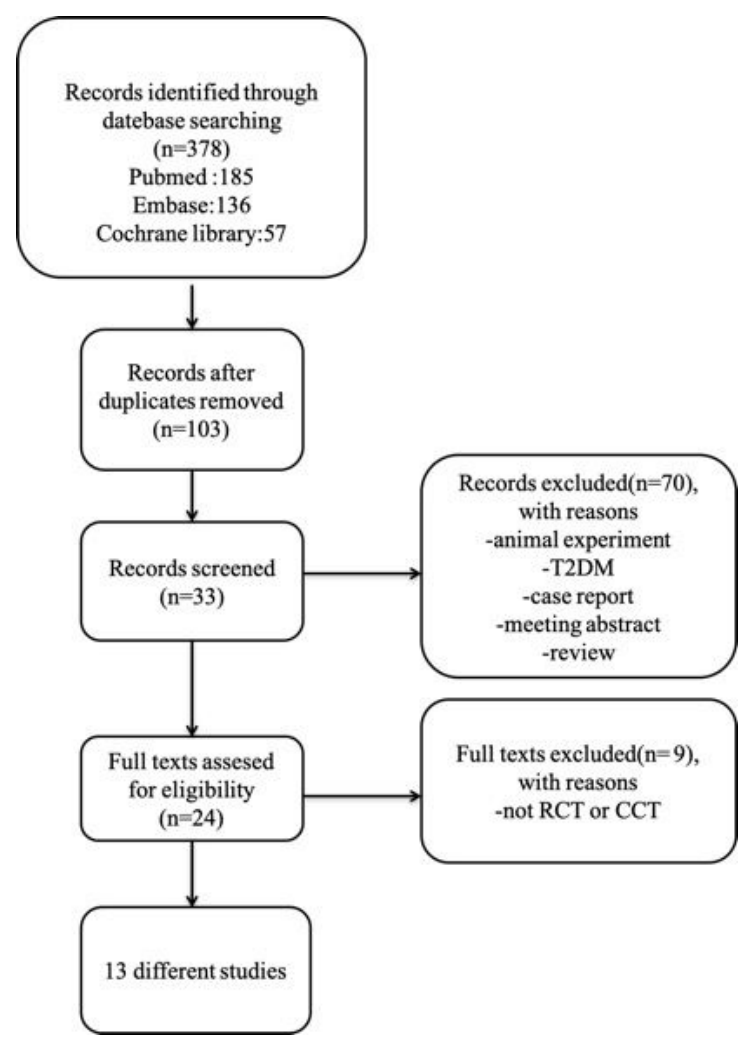

Figure 1

Flow chart

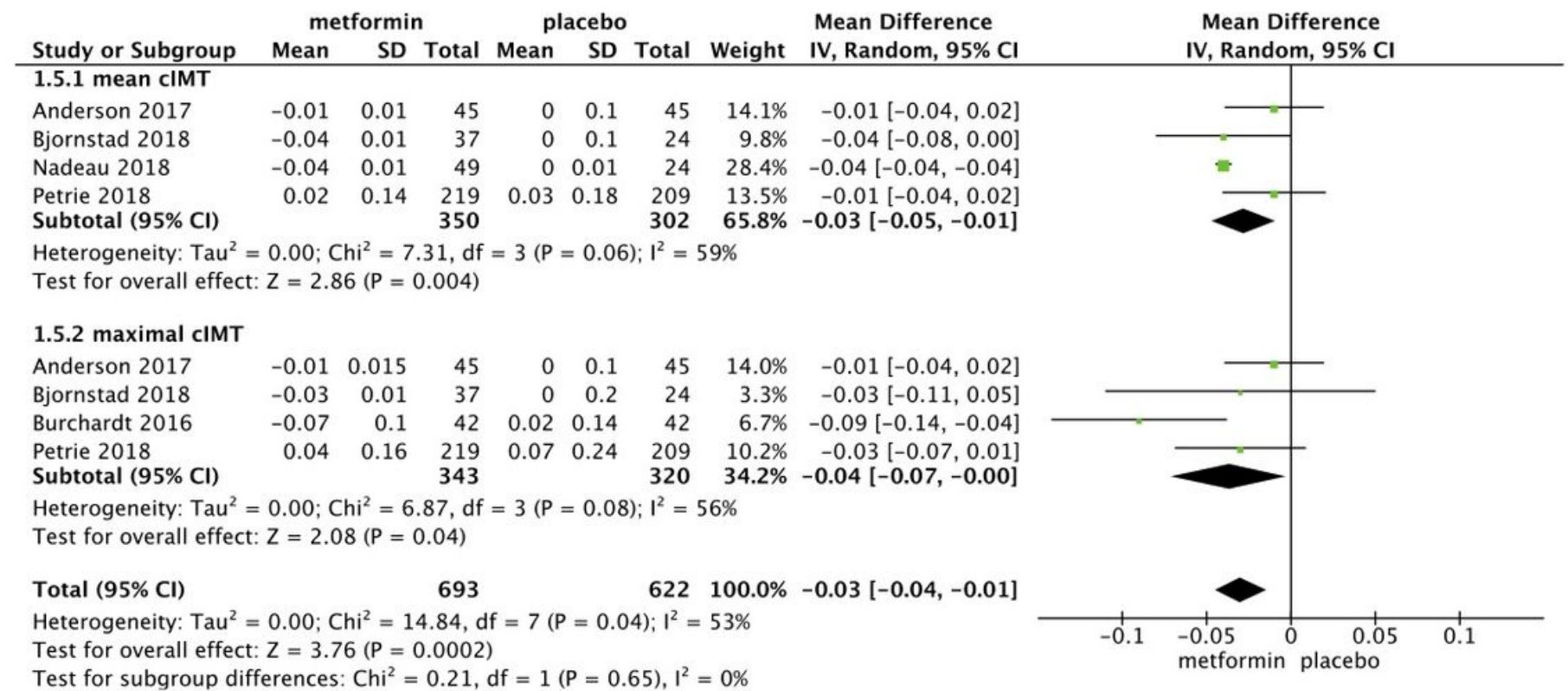

Figure 2

The pooled analysis showed a significant difference between the metformin and placebo groups (MD $-0.04,95 \% \mathrm{Cl}=-0.07-0.0, \mathrm{Z}=2.08, \mathrm{P}=0.04$ ) 


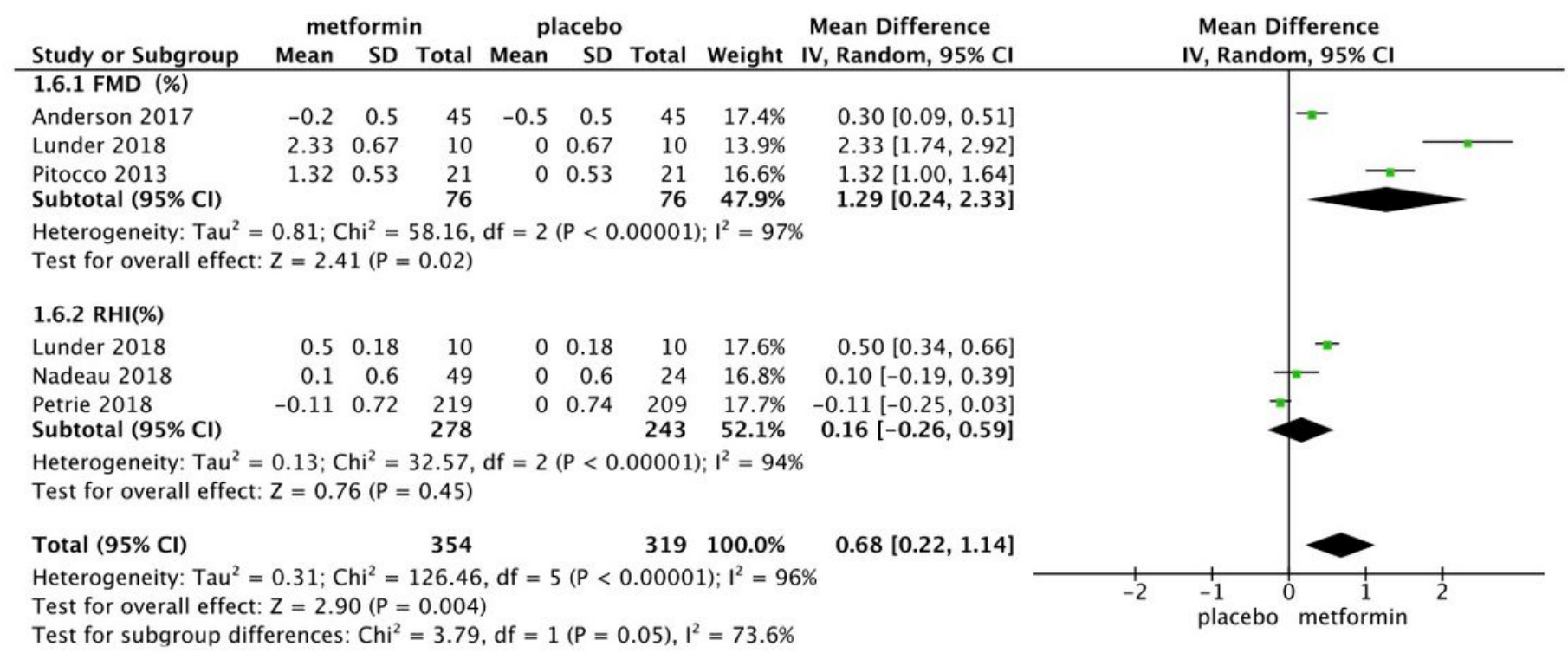

\section{Figure 3}

Three studies provided data on RHI with different treatment regimens (Nadeau 2018, Lunder 2018, Petrie 2018) (heterogeneity: $\mathrm{P}<0.00001 ; \mathbf{I}^{2}=94 \%$ ). Metformin slightly increased $\mathrm{RHI}$ by $0.16 \%(P=0.45)$

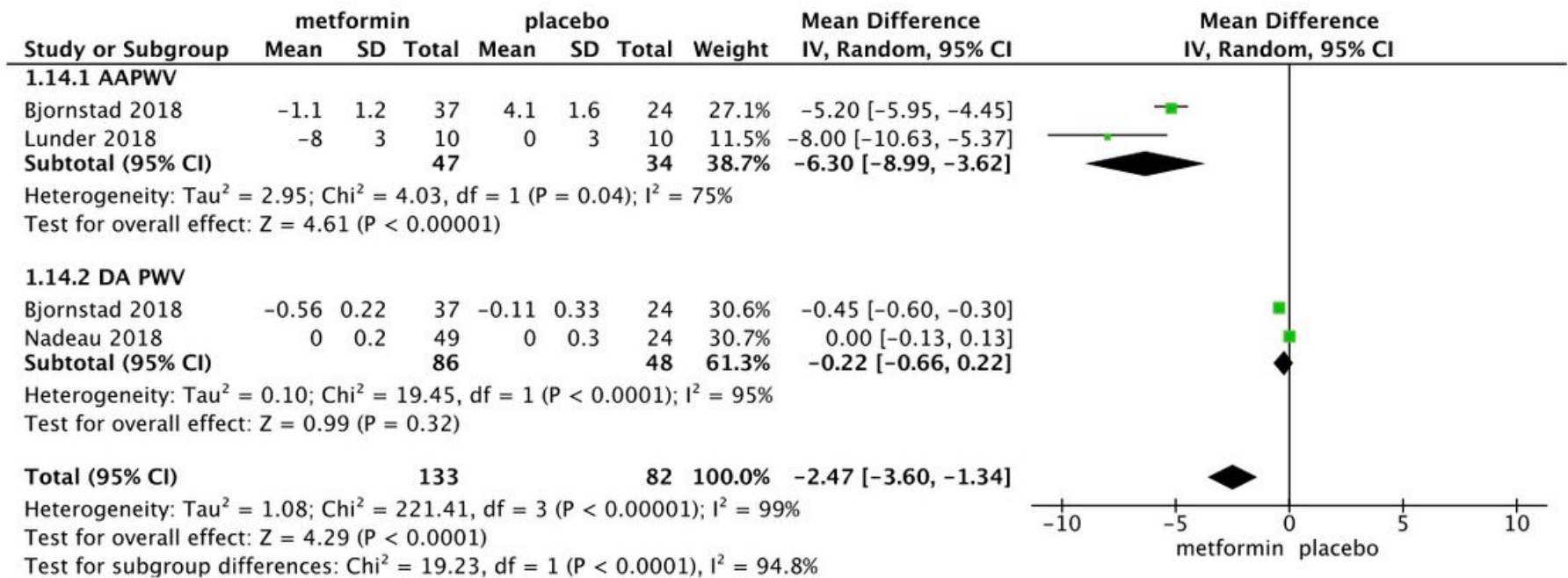

\section{Figure 4}

These 2 studies presented significant heterogeneity $\left(P<0.0001 ; I^{2}=95 \%\right)$. Metformin slightly reduced DA PWV by $0.22 \mathrm{~m} / \mathrm{s}(\mathrm{P}=0.32)$ 


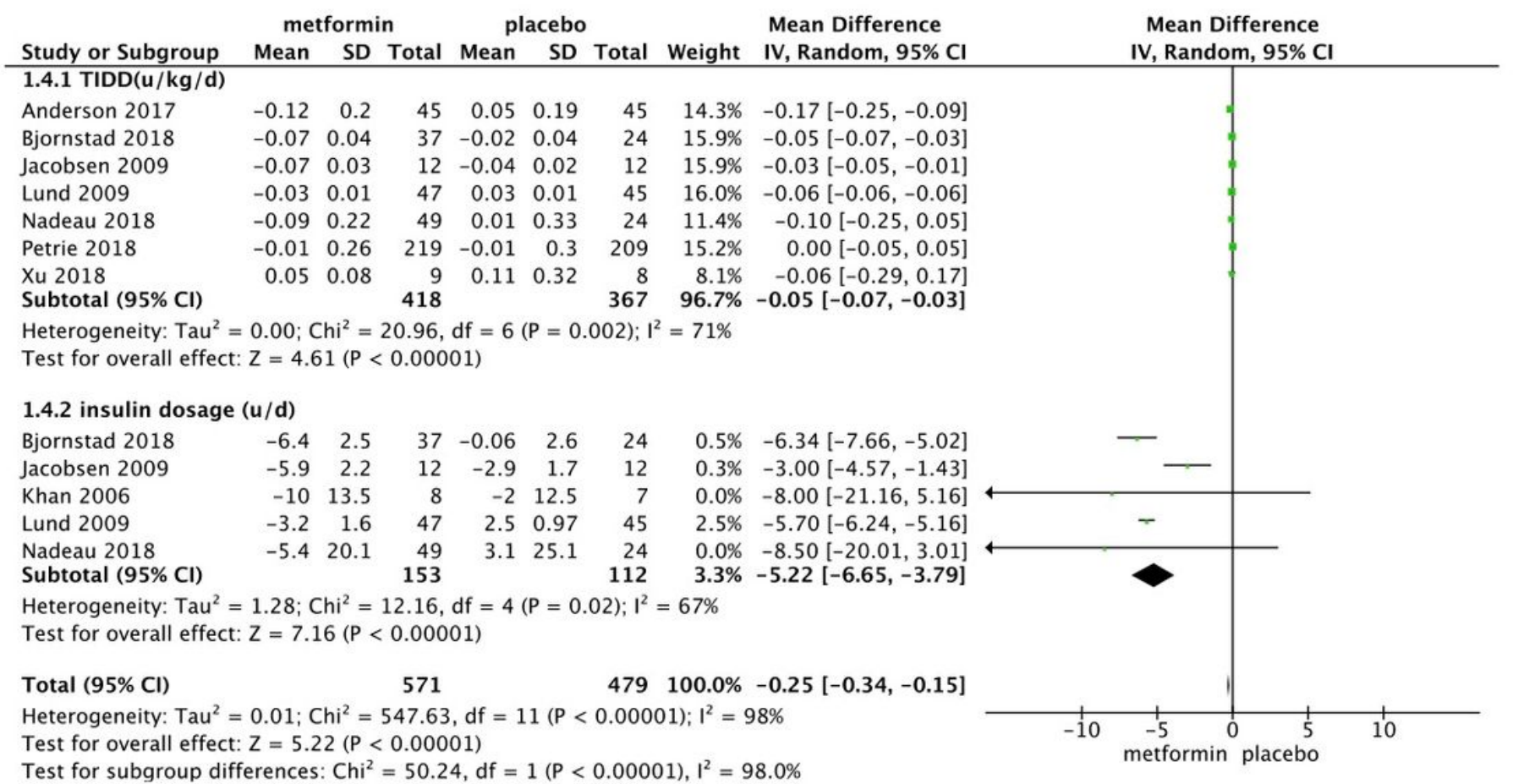

\section{Figure 5}

Metformin significantly reduced daily insulin dosage by $5.22 \mathrm{U} / \mathrm{d}(\mathrm{P}<0.00001)$ 


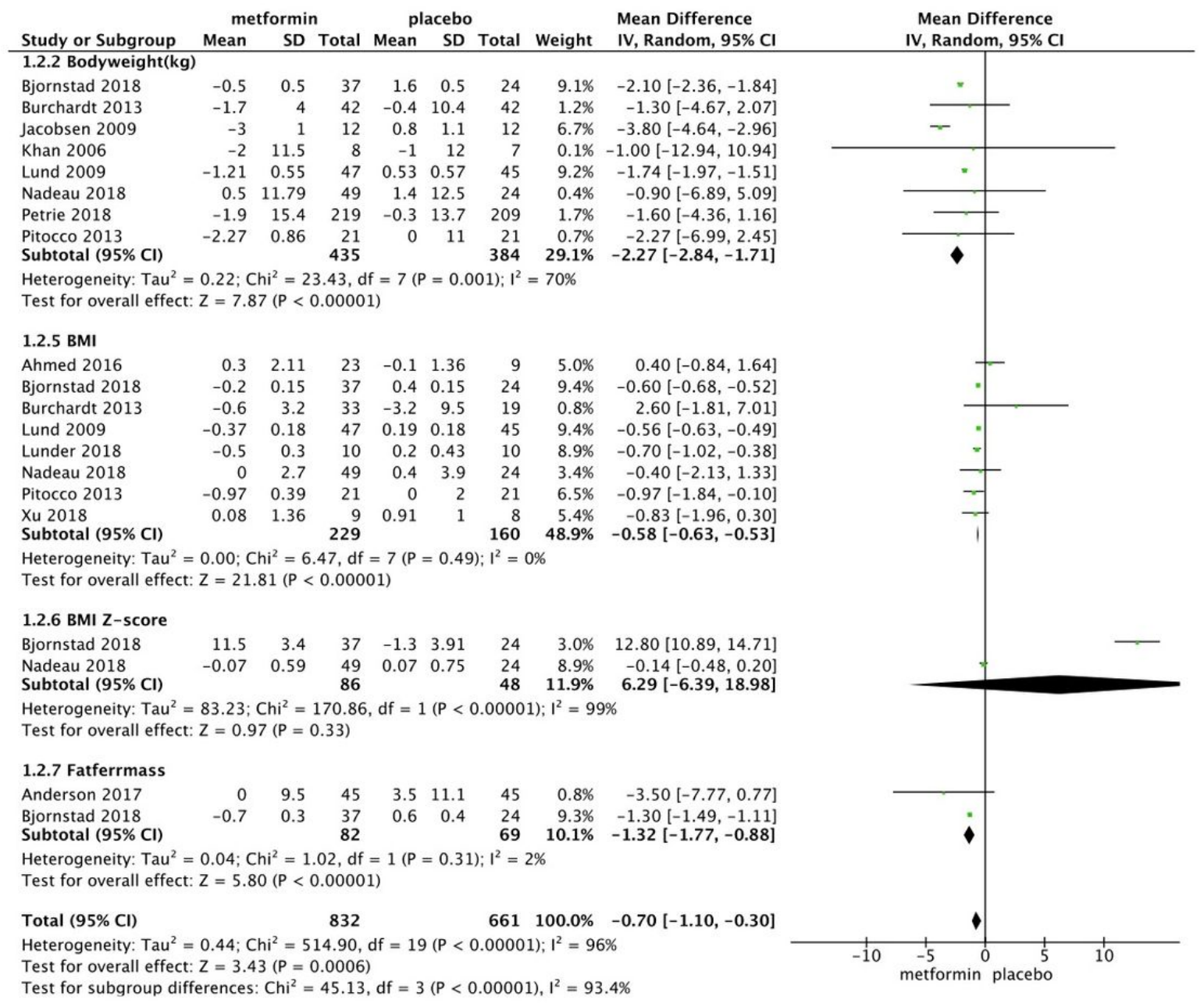

\section{Figure 6}

Bjornstad 2018 and Anderson 2017 provided data on fat-free mass. Heterogeneity was not found $(\mathrm{P}=0.31)$; metformin significantly reduced fat-free mass by $1.32 \mathrm{~kg}(\mathrm{P}<0.00001)$, as shown in Figure 6.

\begin{tabular}{|c|c|c|c|c|c|c|c|c|c|c|c|c|}
\hline \multirow[b]{2}{*}{ Study or Subgroup } & \multicolumn{3}{|c|}{ metformin } & \multicolumn{3}{|c|}{ placebo } & \multirow[b]{2}{*}{ Weight } & \multirow{2}{*}{$\begin{array}{l}\text { Mean Difference } \\
\text { IV, Random, } 95 \% \mathrm{CI}\end{array}$} & \multirow{2}{*}{\multicolumn{3}{|c|}{$\begin{array}{c}\text { Mean Difference } \\
\text { IV, Random, } 95 \% \mathrm{CI}\end{array}$}} & \\
\hline & Mean & SD & Total & Mean & SD & Total & & & & & & \\
\hline Ahmed 2016 & -0.1 & 0.91 & 23 & 0.1 & 1.35 & 9 & $4.0 \%$ & $-0.20[-1.16,0.76]$ & & & & \\
\hline Anderson 2017 & -0.2 & 0.66 & 45 & -0.1 & 0.66 & 45 & $15.1 \%$ & $-0.10[-0.37,0.17]$ & & & - & \\
\hline Bjornstad 2018 & 0.1 & 0.09 & 37 & 0.06 & 0.1 & 24 & $19.7 \%$ & $0.04[-0.01,0.09]$ & & & $=$ & \\
\hline Burchardt 2013 & -0.18 & 0.86 & 33 & -0.19 & 1.05 & 19 & $8.5 \%$ & $0.01[-0.55,0.57]$ & & & & \\
\hline Jacobsen 2009 & -0.09 & 0.18 & 12 & 0.03 & 0.13 & 12 & $18.6 \%$ & $-0.12[-0.25,0.01]$ & & & & \\
\hline Khan 2006 & -0.3 & 1 & 8 & 0 & 1.2 & 7 & $3.1 \%$ & $-0.30[-1.43,0.83]$ & & & & \\
\hline Lund 2009 & -0.33 & 0.11 & 47 & 0.03 & 0.11 & 45 & $19.7 \%$ & $-0.36[-0.40,-0.32]$ & & $=$ & & \\
\hline Nadeau 2018 & -0.04 & 1.01 & 49 & 0.005 & 0.79 & 24 & $11.2 \%$ & $-0.04[-0.47,0.38]$ & & & & \\
\hline Total $(95 \% \mathrm{Cl})$ & & & 254 & & & 185 & $100.0 \%$ & $-0.12[-0.34,0.09]$ & & & & \\
\hline $\begin{array}{l}\text { Heterogeneity: Tau }{ }^{2} \\
\text { Test for overall effec }\end{array}$ & $\begin{array}{l}0.06 \\
Z=1\end{array}$ & $\begin{array}{l}\mathrm{Chi}^{2}= \\
11(\mathrm{P}\end{array}$ & $\begin{aligned} & 139.60 \\
= & 0.27)\end{aligned}$ & $d f=$ & $(P<C$ & 0.0000 & $; 1^{2}=9$ & & ${ }_{-1}^{+}$ & $\begin{array}{l}-0.5 \\
\text { metformin }\end{array}$ & placebo & 1 \\
\hline
\end{tabular}

Figure 7

The heterogeneity disappeared after the removal of Lund $2009\left(P=0.35 ; l^{2}=10 \%\right)$, but the findings were still not statistically significant $(95 \%$ Cl=-0.08- 0.06 , $\mathrm{P}=0.79$ ) 


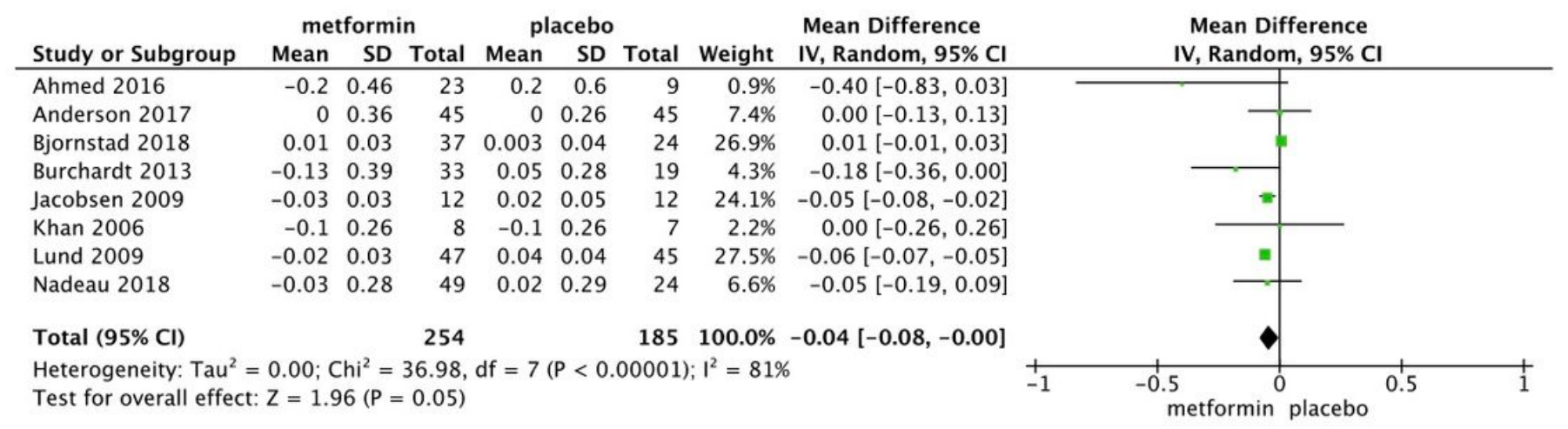

Figure 8

Data on HDL were provided in 8 studies (Ahmed 2016, Anderson 2017, Bjornstad 2018, Burchardt 2013, Jacobsen 2009, Khan 2006, Lund 2009, Nadeau 2018) (heterogeneity: $\left.\mathrm{P}<0.00001 ; \mathrm{I}^{2}=81 \%\right)$. Compared with the placebo, metformin had no effect on $\mathrm{HDL}(95 \% \mathrm{Cl}=-0.08-0.00, \mathrm{P}=0.05)$

\begin{tabular}{|c|c|c|c|c|c|c|c|c|c|c|c|}
\hline \multirow[b]{2}{*}{ Study or Subgroup } & \multicolumn{3}{|c|}{ metformin } & \multicolumn{3}{|c|}{ placebo } & \multirow[b]{2}{*}{ Weight } & \multirow{2}{*}{$\begin{array}{l}\text { Mean Difference } \\
\text { IV, Random, 95\% Cl }\end{array}$} & \multirow{2}{*}{\multicolumn{2}{|c|}{$\begin{array}{c}\text { Mean Difference } \\
\text { IV, Random, } 95 \% \mathrm{CI}\end{array}$}} & \\
\hline & Mean & SD & Total & Mean & SD & Total & & & & & \\
\hline Anderson 2017 & -0.3 & 0.46 & 45 & -0.2 & 0.66 & 45 & $12.5 \%$ & $-0.10[-0.34,0.14]$ & & 1 & \\
\hline Bjornstad 2018 & -0.28 & 0.13 & 37 & -0.18 & 0.14 & 24 & $21.2 \%$ & $-0.10[-0.17,-0.03]$ & -- & & \\
\hline Burchardt 2013 & -0.2 & 0.59 & 33 & -0.1 & 0.93 & 19 & $5.4 \%$ & $-0.10[-0.56,0.36]$ & & & \\
\hline Jacobsen 2009 & -0.23 & 0.16 & 12 & -0.1 & 0.11 & 12 & $19.3 \%$ & $-0.13[-0.24,-0.02]$ & - & & \\
\hline Khan 2006 & -0.2 & 0.85 & 8 & 0.1 & 0.9 & 7 & $1.8 \%$ & $-0.30[-1.19,0.59]$ & & & \\
\hline Lund 2009 & -0.35 & 0.1 & 47 & -0.02 & 0.1 & 45 & $22.2 \%$ & $-0.33[-0.37,-0.29]$ & $=$ & & \\
\hline Petrie 2018 & -0.16 & 0.77 & 219 & -0.04 & 0.72 & 209 & $17.6 \%$ & $-0.12[-0.26,0.02]$ & & & \\
\hline Total $(95 \% \mathrm{Cl})$ & & & 401 & & & 361 & $100.0 \%$ & $-0.16[-0.29,-0.04]$ & & & \\
\hline $\begin{array}{l}\text { Heterogeneity: } \mathrm{Tau}^{2} \\
\text { Test for overall effect }\end{array}$ & $\begin{array}{l}0.02 ; C \\
Z=2.5\end{array}$ & $\begin{array}{l}h^{2}= \\
9(P=\end{array}$ & $\begin{array}{l}42.17 \\
0.010)\end{array}$ & $\mathrm{df}=$ & $P<$ & 0001) & $1^{2}=86 \%$ & & $\begin{array}{l}-0.5 \quad 0 \\
\text { metformin }\end{array}$ & $0 \quad 0.5$ & 1 \\
\hline
\end{tabular}

Figure 9

Metformin significantly reduced LDL by $0.11 \mathrm{mmol} / \mathrm{L}(95 \% \mathrm{Cl}=-0.16-0.06, \mathrm{Z}=4.11, \mathrm{P}<0.0001)$

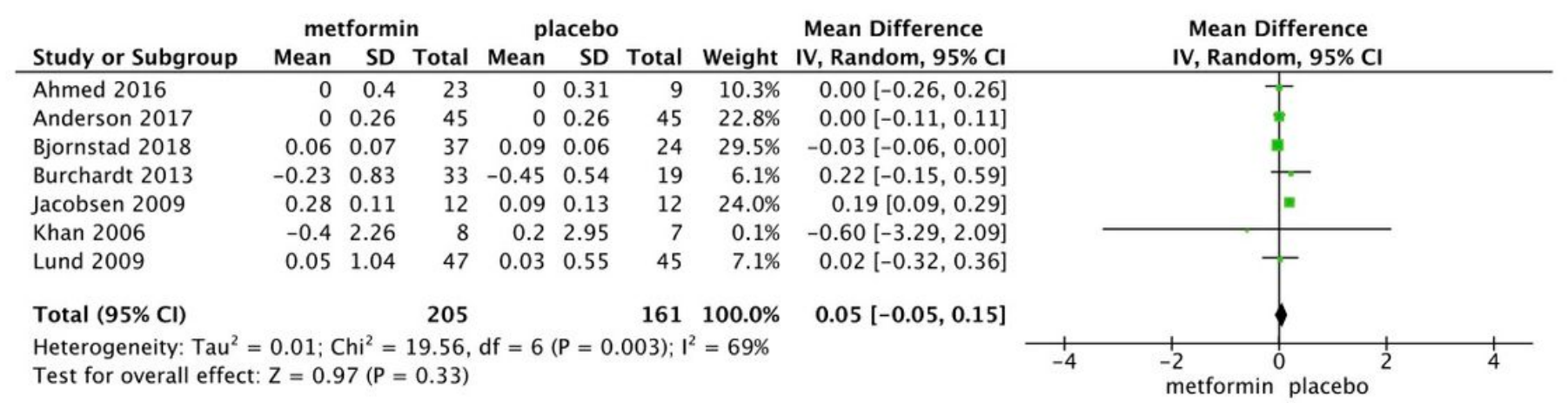

\section{Figure 10}

The heterogeneity disappeared after the removal of Bjornstad $2018\left(P=0.15 ; I^{2}=38 \%\right)$ and Jacobsen $2009\left(P=0.82 ; I^{2}=0 \%\right)$, but the results were still not statistically significant 


\begin{tabular}{|c|c|c|c|c|c|c|c|c|c|c|c|c|}
\hline \multirow[b]{2}{*}{ Study or Subgroup } & \multicolumn{3}{|c|}{ metformin } & \multicolumn{3}{|c|}{ placebo } & \multirow{3}{*}{ Weight } & \multirow{3}{*}{$\begin{array}{l}\text { Mean Difference } \\
\text { IV, Random, } 95 \% \mathrm{CI}\end{array}$} & \multirow{2}{*}{\multicolumn{4}{|c|}{$\begin{array}{l}\text { Mean Difference } \\
\text { IV, Random, } 95 \% \mathrm{Cl}\end{array}$}} \\
\hline & Mean & SD & Total & Mean & SD & Total & & & & & & \\
\hline \multicolumn{11}{|c|}{ 1.9.1 Waist circumference $(\mathrm{m})$} & & \\
\hline Anderson 2017 & -0.18 & 0.85 & 45 & 0.22 & 0.11 & 45 & $10.2 \%$ & $-0.40[-0.65,-0.15]$ & & & & \\
\hline Lund 2009 & -0.26 & 0.71 & 47 & -0.06 & 0.75 & 45 & $8.9 \%$ & $-0.20[-0.50,0.10]$ & & & & \\
\hline Lunder 2018 & 0.1 & 0.45 & 10 & -0.17 & 0.37 & 10 & $7.4 \%$ & $0.27[-0.09,0.63]$ & & & & \\
\hline Nadeau 2018 & -0.14 & 0.86 & 49 & 0.4 & 0.84 & 24 & $6.3 \%$ & $-0.54[-0.95,-0.13]$ & $\leftarrow$ & & & \\
\hline $\begin{array}{l}\text { Xu } 2018 \\
\text { Subtotal }(95 \% \mathrm{CI})\end{array}$ & 0.8 & 0.33 & $\begin{array}{r}9 \\
160\end{array}$ & 0.36 & 0.27 & $\begin{array}{r}8 \\
132\end{array}$ & $\begin{array}{r}9.3 \% \\
42.1 \%\end{array}$ & $\begin{array}{r}0.44[0.15,0.73] \\
-0.08[-0.45,0.29]\end{array}$ & & & & \\
\hline \multicolumn{11}{|c|}{$\begin{array}{l}\text { Heterogeneity: } \mathrm{Tau}^{2}=0.15 ; \mathrm{Chi}^{2}=28.00, \mathrm{df}=4(\mathrm{P}<0.0001) ; \mathrm{I}^{2}=86 \% \\
\text { Test for overall effect: } \mathrm{Z}=0.43(P=0.67)\end{array}$} & & \\
\hline \multicolumn{13}{|c|}{ 1.9.2 Hip circumference $(\mathrm{m})$} \\
\hline Anderson 2017 & 0.1 & 0.84 & 45 & 0.36 & 0.1 & 45 & $10.3 \%$ & $-0.26[-0.51,-0.01]$ & & & & \\
\hline $\begin{array}{l}\text { Lund } 2009 \\
\text { Subtotal }(95 \% \mathrm{CI})\end{array}$ & -0.139 & 0.07 & $\begin{array}{l}47 \\
92\end{array}$ & 0.15 & 0.08 & $\begin{array}{l}45 \\
90\end{array}$ & $\begin{array}{l}15.8 \% \\
26.2 \%\end{array}$ & $\begin{array}{l}-0.29[-0.32,-0.26] \\
-0.29[-0.32,-0.26]\end{array}$ & & - & & \\
\hline \multicolumn{13}{|c|}{$\begin{array}{l}\text { Heterogeneity: } \mathrm{Tau}^{2}=0.00 ; \mathrm{Chi}^{2}=0.05, \mathrm{df}=1(\mathrm{P}=0.82) ; \mathrm{I}^{2}=0 \% \\
\text { Test for overall effect: } \mathrm{Z}=18.52(P<0.00001)\end{array}$} \\
\hline \multicolumn{13}{|l|}{ 1.9.3 Waist/Hipratio } \\
\hline Anderson 2017 & 0 & 0.09 & 45 & 0 & 0.09 & 45 & $15.8 \%$ & $0.00[-0.04,0.04]$ & & & + & \\
\hline $\begin{array}{l}\text { Lund } 2009 \\
\text { Subtotal }(95 \% \mathrm{CI})\end{array}$ & 0.01 & 0.01 & $\begin{array}{l}47 \\
92\end{array}$ & -0.01 & 0.01 & $\begin{array}{l}45 \\
90\end{array}$ & $\begin{array}{l}15.9 \% \\
31.7 \%\end{array}$ & $\begin{array}{l}0.02[0.02,0.02] \\
0.02[0.01,0.03]\end{array}$ & & & 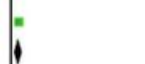 & \\
\hline \multicolumn{13}{|c|}{$\begin{array}{l}\text { Heterogeneity: } \mathrm{Tau}^{2}=0.00 ; \mathrm{Chi}^{2}=1.10, \mathrm{df}=1(\mathrm{P}=0.29) ; \mathrm{I}^{2}=9 \% \\
\text { Test for overall effect: } Z=4.13(P<0.0001)\end{array}$} \\
\hline Total $(95 \% \mathrm{Cl})$ & & & 344 & & & 312 & $100.0 \%$ & $-0.10[-0.24,0.03]$ & & & & \\
\hline \multicolumn{9}{|c|}{$\begin{array}{l}\text { Heterogeneity: } \mathrm{Tau}^{2}=0.03 ; \mathrm{Chi}^{2}=415.86, \mathrm{df}=8(\mathrm{P}<0.00001) ; \mathrm{I}^{2}=98 \% \\
\text { Test for overall effect: } \mathrm{Z}=1.49(\mathrm{P}=0.14) \\
\text { Test for subgroup differences: } \mathrm{Chi}^{2}=358.67, \mathrm{df}=2(\mathrm{P}<0.00001), \mathrm{I}^{2}=99.4 \%\end{array}$} & -0.5 & -0.25 & 0.25 & 0.5 \\
\hline
\end{tabular}

\section{Figure 11}

Anderson 2017 and Lund 2009 provided data on the waist-to-hip ratio (heterogeneity: $P=0.29 ; I^{2}=9 \%$ ). Metformin significantly reduced the waist-to-hip ratio by $0.02(P<0.0001)$

\begin{tabular}{|c|c|c|c|c|c|c|c|c|c|c|c|c|}
\hline \multirow[b]{2}{*}{ Study or Subgroup } & \multicolumn{3}{|c|}{ metformin } & \multicolumn{3}{|c|}{ placebo } & \multirow{2}{*}{\multicolumn{2}{|c|}{$\begin{array}{cc} & \text { Mean Difference } \\
\text { Weight } & \text { IV, Random, } 95 \% \mathrm{CI} \\
\end{array}$}} & \multirow{2}{*}{\multicolumn{4}{|c|}{$\begin{array}{l}\text { Mean Difference } \\
\text { IV, Random, } 95 \% \mathrm{Cl}\end{array}$}} \\
\hline & Mean & SD & Total & Mean & SD & Total & & & & & & \\
\hline \multicolumn{13}{|c|}{ 1.3.1 Systolic BP $(\mathrm{mmHg})$} \\
\hline Ahmed 2016 & -4 & 12.7 & 23 & -2 & 10.47 & 9 & $3.1 \%$ & $-2.00[-10.59,6.59]$ & & & & \\
\hline Anderson 2017 & -2 & 8.5 & 45 & 0.4 & 7.5 & 45 & $8.7 \%$ & $-2.40[-5.71,0.91]$ & & & 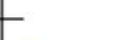 & \\
\hline Bjornstad 2018 & -0.7 & 1.7 & 37 & -1.7 & 1.8 & 24 & $12.3 \%$ & $1.00[0.10,1.90]$ & & & - & \\
\hline Jacobsen 2009 & -1.1 & 4.8 & 12 & -4.2 & 6.7 & 12 & $6.6 \%$ & $3.10[-1.56,7.76]$ & & & & \\
\hline Lunder 2018 & -6.5 & 2.7 & 10 & -2.5 & 3.6 & 10 & $9.5 \%$ & $-4.00[-6.79,-1.21]$ & & & & \\
\hline $\begin{array}{l}\text { Nadeau } 2018 \\
\text { Subtotal }(95 \% \mathrm{Cl})\end{array}$ & -1.8 & 13.8 & $\begin{array}{r}49 \\
176\end{array}$ & 3.3 & 11.8 & $\begin{array}{r}24 \\
124\end{array}$ & $\begin{array}{r}4.9 \% \\
45.1 \%\end{array}$ & $\begin{array}{r}-5.10[-11.20,1.00] \\
-1.29[-3.94,1.36]\end{array}$ & & & & \\
\hline \multicolumn{13}{|c|}{$\begin{array}{l}\text { Heterogeneity: } \text { Tau }^{2}=6.67 ; \mathrm{Chi}^{2}=18.65, \mathrm{df}=5(\mathrm{P}=0.002) ; \mathrm{I}^{2}=73 \% \\
\text { Test for overall effect: } \mathrm{Z}=0.95(\mathrm{P}=0.34)\end{array}$} \\
\hline \multicolumn{13}{|c|}{ 1.3.2 Diastolic BP $(\mathrm{mmHg})$} \\
\hline Ahmed 2016 & -2.2 & 8.32 & 23 & -4.1 & 7.11 & 9 & $5.3 \%$ & $1.90[-3.86,7.66]$ & & & & \\
\hline Anderson 2017 & -1.3 & 5.6 & 45 & 0.2 & 4.7 & 45 & $10.6 \%$ & $-1.50[-3.64,0.64]$ & & & & \\
\hline Bjornstad 2018 & -2.2 & 1.4 & 37 & -0.2 & 1.5 & 24 & $12.4 \%$ & $-2.00[-2.75,-1.25]$ & & - & & \\
\hline Jacobsen 2009 & -2.4 & 2.6 & 12 & -8.7 & 3.5 & 12 & $10.1 \%$ & $6.30[3.83,8.77]$ & & & & \\
\hline Lunder 2018 & 0.7 & 2 & 10 & 3.8 & 4.7 & 10 & $8.9 \%$ & $-3.10[-6.27,0.07]$ & & & & \\
\hline $\begin{array}{l}\text { Nadeau } 2018 \\
\text { Subtotal }(95 \% \mathrm{CI})\end{array}$ & -1.8 & 7.3 & $\begin{array}{r}49 \\
176\end{array}$ & 2.5 & 8.6 & $\begin{array}{r}24 \\
124\end{array}$ & $\begin{array}{r}7.6 \% \\
54.9 \%\end{array}$ & $\begin{array}{l}-4.30[-8.30,-0.30] \\
-0.49[-3.38,2.40]\end{array}$ & & & & \\
\hline \multicolumn{13}{|c|}{$\begin{array}{l}\text { Heterogeneity: } \mathrm{Tau}^{2}=10.51 ; \mathrm{Chi}^{2}=44.27, \mathrm{df}=5(\mathrm{P}<0.00001) ; \mathrm{I}^{2}=89 \% \\
\text { Test for overall effect: } Z=0.33(\mathrm{P}=0.74)\end{array}$} \\
\hline \multirow{2}{*}{\multicolumn{9}{|c|}{$\begin{array}{l}\text { Total }(95 \% \mathrm{Cl}) \\
\text { Heterogeneity: } \mathrm{Tau}^{2}=6.15 ; \mathrm{Chi}^{2}=73.64, \mathrm{~d} \\
\text { Test for overall effect: } \mathrm{Z}=0.96(\mathrm{P}=0.34) \\
\text { Test for subgroup differences: } \mathrm{Chi}^{2}=0.16 \text {, }\end{array}$}} & & & & \\
\hline & & & & & & & & & -10 & $\begin{array}{l}-5 \\
\text { metformin }\end{array}$ & placebo $^{5}$ & 10 \\
\hline
\end{tabular}

\section{Figure 12}

